\title{
Comment on the Request for the Constitution of a Section on Viral Taxonomy in I.A.M.S.
}

The following is a statement of personal views concerning the request for the formation of a Section on Viral Taxonomy in the International Association of Microbiological Societies (IAMS). These are quite unofficial, and may or may not be representative of the views of the members of the Judicial Commission of which I am Chairman. The views of the several members of the Commission, or a summary of their views, will be published later.

A Subcommittee on Taxonomy of the Viruses was recognized and constituted by the International Committee on Bacteriological Nomenclature and approved by the Plenary Session of the International Congress for Microbiology at Rio de Janeiro in 1950. This subcommittee has requested that it be dissolved by action of the Executive Committee of the International Association of Microbiological Societies and that it be reconstituted by the said Executive Committee as a Section on Taxonomy of the Viruses. It is requested that this committee be coordinate with the International Committee (Section) on Bacteriological Nomenclature and report directly to the International Association of Microbiological Societies. A copy of the letter from Sir Christopher Andrewes, Chairman of the Subcommittee to Dr. Lwoff, President of I.A.M.S., with a letter of transmittal from Dr. Cowan, Chairman of the International Committee on Bacteriological Nomenclature, was published in this Bulletin (July, 1963). Requests for comments were made by Chairman Cowan of the International Committee and by the Chairman of the Judicial Commission of the International Committee.

The request of the present Subcommittee is a reasonable and natural one. It is not the result of any denial of any request made by the Subcommittee to the International Committee. Presumably the primary reason for the request is that virology has reached the status of a discipline coordinate with the disciplines of botany, zoology and bacteriology, and should develop its own Code of Nomenclature. A secondary reason may be the objection raised on the part of some virologists to what they term "Linnaean" taxonomy. This latter objection has never been formulated definitely in reports to the International Committee; just what "Linnaean" 
taxonomy means has never been clearly defined. The opinion has been expressed by some virologists that the use of binary combinations as names for species is not appropriate for vurises, even though such use is customary and universal in all the other biological disciplines.

That virology has come of age and should be recognized as a major biological discipline seems evident and logical. Within the last decade it has become increasingly clear that the bacteria and the vira constitute distinct groups. They are readily differentiable as to taxa. That the Rickettsiales do not constitute an intermediate group between the bacteria and viruses (vira) seems demonstrable. They are not vira but bacteria much modified by their existence as obligate parasites. There seems to be little danger of confusion between the bacteria and the vira.

If the request of the Subcommittee on Taxonomy of the Viruses is approved and a Section on Taxonomy of the Viruses created in the I.A.M.S., there will necessarily follow some readjustments in bacteriology. For example, the name of the code governing bacteriological nomenclature prior to 1953 had been designated as the "International Bacteriological Code of Nomenclature." A revision of the Code was approved by the Judicial Commission and the name changed to the "International Code of Nomenclature of the Bacteria and Viruses." The change was approved by the International Committee and the Plenary Session of the International Microbiological Congress at Rome in 1953. Presumably the members of the Judicial Commission assumed that special provisions to fit the requirements of virology would be recommended. No recommendation for amendment has been received from the Subcommittee.

The first suggestion to the International Committee for the formation of a Subcommittee on Animal Virus Nomenclature was made at the meeting of the International Committee in New York in 1939 (through Prof. Breed, one of the Permanent Secretaries of the International Committee) by Prof. James Johnson, Recorder of the International Committee on Plant Virus Nomenclature of the International Botanical Congress. It should be noted that the Bacteriological Code had not at that time been formulated. There was no precedent for the formation of such a Subcommittee. Provision for creation of subcommittees on taxonomy of designated taxa was included in the Code adopted at Copen- 
hagen in 1947. The request of 1939 was not for a subcommittee on viral taxonomy but on viral nomenclature.

The Subcommittee on Taxonomy of the Viruses was constituted by action of the International Committee and the International Congress at Rio de Janeiro in 1950. A history of the Subcommittee as revealed in official actions by the Judicial Commission, the International Committee and the reports of the Subcommittee is in process of preparation. It is hoped that it may be published in the January 1964 issue of the International Bulletin of Bacteriological Nomenclature and Taxonomy.

It may be anticipated that the new Section of Viral Taxonomy, if authorized, will be a section of the International Association of Microbiological Societies and function in conformity with biological custom. The Subcommittee is to be commended for its outstanding leadership in determination of relationships and logical classification of the viruses. It may be assumed that the Section, if formed, will recognize that the scientific (not the vernacular) names recommended for each virus should be reasonably consonant with custom in the other three major biological disciplines. Many more biologists in the other biological disciplines than virologists will be using the scientific names of the vira. When proposed, these scientific names are no longer the property of virologists; they constitute an essential part of the vocabulary of biology. It is anticipated that viral rules of nomenclature and the kinds of names proposed will be adapted to the needs of virology and in general consistent with practically universal biological usage.

R.E. Buchanan

Ames, Iowa, U.S.A.

21 st August, 1963 
